\title{
A New Paradigm for Developing Effective Anti-Cancer Therapeutics
}

\author{
Karel Petrak* \\ NangioTx Inc, USA
}

Submission: April 24, 2017 ; Published: May 02, 2017

"Correspondence Address: Karel Petrak, NangioTx, Inc.,555 5th Avenue, New York, NY10017,USA, Tel:6786131386;Email:klpetrak@gmail.com

Abstract

Despite major research efforts in understanding cancer and in developing drugs and drug-delivery system, progress towards significantly improved anticancer drugs has been slow. In this brief contribution, a new paradigm for developing new anticancer drugs is presented.

\section{Opinion}

Research aiming to understand and treat cancer is a huge effort. The American Cancer Society alone invested more than $\$ 4.5$ billion in cancer research since 1946 to find better treatments, factors that may cause cancer, and improve cancer patients' quality of life [1].

As of 24 April 2017, there were 778,629 publications recorded in PubMed over the last 5 years. 45,766 of these reported on "cancer AND mechanism", and 9,889 on "cancer AND new AND mechanism". During the first four months of this year (2017) alone, some 967 publications appeared that reported on "cancer AND new AND mechanism".

Many cellular and biochemical pathways have been reported to be involved in cancer initiation and progression - here is a very short list: $\mathrm{ALK}=$ anaplastic lymphoma kinase; $\mathrm{BAD}=\mathrm{bcl}-2-$ associated death promoter protein; EML4=echinoderm microtubule-associated protein-like 4; ERK=extracellular signalregulated kinase; $\mathrm{IP}_{3}=$ inositol trisphosphate; $\mathrm{MEK}=$ mitogenactivated protein kinase/ERK kinase; $m T O R=$ mammalian target of rapamycin; $\mathrm{PI} 3 \mathrm{~K}=$ phosphatidylinositol 3-kinase; PIP2=phosphatidylinositol 3,4-bisphosphate; PLC$\gamma=$ phospholipase $\quad \mathrm{C}-\gamma ; \quad \mathrm{S} 6 \mathrm{~K}=\mathrm{S} 6 \quad$ kinase; $\quad$ STAT3 $/ 5=$ signal transducer and activator of transcription 3/5; B-cell lymphoma 2, mitogen-activated protein kinase (MAPK), Human epidermal growth factor receptor (HER), programmed death-ligand 1 (PDL1) , phosphatidylinositol 3-kinase (PI3K), vascular endothelial growth factor (VEGF) [2].

And the list is growing. Recently Chen etal. briefly summarized the function and molecular mechanisms of lincRNa-p21 in cancer and its regulation for the genes expression [3]. Wang et al. [4] suggested that IncRNAs may be "promising" therapeutic molecules to eradicate cancer stem cells. LincRNA-p21 were also suggested by others in the growth of vascular endothelial cells [5]. Gutschner and Diederichs [6] extrapolated existing information and linked the cellular processesinfluenced by long ncRNAs to the "hallmarks of cancer" and proposed that "this should stimulate new researchdirections and therapeutic options considering long ncRNAs as novel prognosticmarkers and therapeutic targets".Extracellular vesicles (EVs) have also been suggested to have a potential to be new diagnostic biomarkers and new therapeutic targets for cancer [7].

Small interfering RNAs have function in post-transcriptional regulation ingastric cancer are being thought as having potential utility in gastric cancer treatment [8].

It is often the case that basic research conducted at academic institution does not become readily converted into therapeutic products. While "promising" research results are published, this is in most cases not followed up by reducing the idea to practice [9]. Effective treatment of cancer should ideally correct or remove aberrant cancer cells while leaving normal cells intact. One approach is to generate new molecules that act with high specificity on the cancer targets. Let us first recognize that the term "targeting / targeted drug" is being used to describe too different situations.

A. Drug action is directed to a molecular structure associated with the mechanism of disease but also present on a non-diseased/normal tissue (i.e., tumor-associated antigens (TAAs);

B. Drug action is directed to a molecular structure uniquely associated with the disease and only at a specific disease sites (i.e., tumor-specific antigens (TSAs). 


\section{Cancer Therapy \& Oncology International Journal}

Obviously employing the approach above is not suitable for generating effective anti-cancer drugs.

There remains a large chasm between the disciplines of chemistry and material science that create new delivery systems and tests these largely in vitro, and biology that works towards understanding biological mechanisms that maintain health or generate diseases. Using approaches that has not work well enough for decades need to be replaced by a new paradigm. Let me propose one.

A. Drug research should pursue development of highly specific drugs capable of interacting with unique structures associated with newly identified biological mechanisms of cancer initiation and progression. The current representative of such drugs are therapeutic antibodies [10] that are, however not ideal, with their disadvantages stemming from their large size (and hence difficulty to access disease sites). A part of the new paradigm is not to rely on the current, conventional process of drug testing (i.e., highenough solubility, broad distribution throughout the body). Drugs having low solubility but exhibiting high selectivity in vitro(e.g., as determined by binding to specific diseaserelevant molecular structures) should not be rejected; instead, it should be recognized that such drugs are ideally suited to be "targeted", i.e., delivered to, and released in their active form at sites of disease.

B. For such new drugs, the appropriate delivery system should be selected from the existing "arsenal" of delivery systems. It is likely that none of the existing systems proves to be adequate; hence, new, appropriately "tailored" combinations of drug and delivery system may need to be invented. Whether the existing "natural" delivery systems (such as EVs) could be used effectively remains to be a matter of conjecture [11-12].
However, it is obvious that material science and biology will need to work much more closely together in defining unique features of disease on which effective drug-delivery systems could be based.

\section{Reference}

1. Cancer facts and statistics.

2. Disease pathways and cancer exploration.

3. Chen S, Liang H, Yang H (2017) LincRNa-p21: function and mechanism in cancer. Med Oncol 34(5): 98.

4. Wang J, Lei ZJ, Guo Y, Wang T, Qin ZY, et al. (2015) miRNAregulated delivery of lincRNA-p21 suppresses $\beta$-catenin signaling andtumorigenicity of colorectal cancer stem cells. Oncotarget 6(35): 37852-37870.

5. He C, Ding JW, Li S, Wu H, Jiang YR, et al. (2015) The Role of Long Intergenic Noncoding RNA p21 in Vascular Endothelial Cells. DNA Cell Biol 34(11): 677-683.

6. Gutschner T, Diederichs S (2012) The hallmarks of cancer: a long noncoding RNA point of view. RNA Biol 9(6): 703-719.

7. Ma P, Pan Y, Li W, Sun C, Liu J, et al. (2017) Extracellular vesiclesmediated noncoding RNAs transfer in cancer. J Hematol Oncol 10(1): 57.

8. Li PF, Chen SC, Xia T, Jiang XM, Shao YF, et al. (2014) Non-coding RNAs and gastric cancer. World J Gastroenterol 20(18): 5411-5419.

9. Petrak K (2013) Targeting Drug-Delivery Systems: Promises, Promises, and More Promises. Let's Change the Paradigm" in Recent Advances in Drug Delivery Research. 167-180.

10. Petrak K (2015) Antibodies - The "Magic Bullets" for Drug Delivery? Int J Drug Dev \& Res 7: 26-28.

11. Luan X, Sansanaphongpricha K, Myers I, Chen H, Yuan H, et al. (2017) Engineering exosomes as refined biological nanoplatforms for drug delivery. Acta Pharmacol Sin 10.

12. Syn NL, Wang L, Chow EK, Lim CT, Goh BC (2017) Exosomes in Cancer Nanomedicine and Immunotherapy: Prospects and Challenges. Trends Biotechnol 7799(17): 30040-30049.

This work is licensed under Creative Commons Attribution 4.0 License

DOI:_10.19080/CTOIJ.2017.04.555649

\section{Your next submission with Juniper Publishers} will reach you the below assets

- Quality Editorial service

- Swift Peer Review

- Reprints availability

- E-prints Service

- Manuscript Podcast for convenient understanding

- Global attainment for your research

- Manuscript accessibility in different formats

( Pdf, E-pub, Full Text, Audio)

- Unceasing customer service

Track the below URL for one-step submission https://juniperpublishers.com/online-submission.php 